\title{
Hydrothermal Carbonization of Waste Babassu Coconut Biomass for Solid Fuel Production
}

\author{
Costa, R. S.; * Vieira, L. H. S.; Ghosh, A.; Santos, A. M. S.; Ferreira, O. P.; \\ Viana, B. C.
}

Rev. Virtual Quim., 2019, 11 (3), 626-641. Data de publicação na Web: 2 de maio de 2019

http://rvq.sbq.org.br

\section{Carbonização Hidrotérmica de Resíduos de Biomassa de Coco Babaçu para Produção de Combustíveis Sólidos}

Resumo: Vários resíduos de biomassas se apresentam com potenciais para a produção de combustível sólido usando técnicas de carbonização para seu adensamento energético. A síntese de materiais carbonáceos com diferentes morfologias, porosidades e composição química, utilizando carbonização hidrotérmica, uma técnica simples e de baixo custo, apresentou potencial para agregar valor à cadeia de produção de babaçu, um fruto regional, comum no norte nordeste do Brasil. Neste trabalho, duas importantes biomassas derivadas do coco do babaçu, denominadas mesocarpo e farelo de babaçu, foram utilizadas como precursoras para a produção de materiais estruturados carbonáceos via carbonização hidrotérmica. Os carbonos hidrotérmicos produzidos (HTCs) foram caracterizados e suas propriedades como combustíveis foram avaliadas. O valor calorífico bruto (HHV) revelou valores de até 24,83 MJ / kg para o carbono hidrotérmico do mesocarpo e até 28,91 MJ / kg para o carbono hidrotérmico do farelo de babaçu, apresentando um aumento de 69 e $89 \%$ no adensamento energético, respectivamente, em comparação com a respectiva biomassa residual de precursores. Além disso, verificou-se um aumento na densidade energética desses carbonos com o aumento da temperatura de síntese. As análises químicas mostraram que a eficiência de combustão dos carbonos hidrotérmicos de mesocarpo melhorou, além de haver redução do teor de cinzas, e melhorias na matéria volátil e quantidade de oxigênio, bem como os incrementos nos teores de carbono total e carbono fixo. A evolução da carbonização da biomassa, determinada pelas medidas de FT-IR e Raman, mostraram que a maioria dos carboidratos e proteínas foi decomposta acima de $160^{\circ} \mathrm{C}$. A aromaticidade dos carbonos hidrotérmicos aumentou com o aumento temperatura, enquanto quantidades consideráveis de grupos funcionais permaneceram após o tratamento hidrotérmico.

Palavras-chave: Biomassa de coco babaçu; combustíveis sólidos; carbono hidrotérmico; propriedades energéticas; carbonização de biomassa.

\begin{abstract}
Different waste biomasses have enormous potential for the production of solid fuel using carbonization techniques to many ene rgy purposes. Synthesis of carbonaceous materials with different morphologies, porosity and chemical composition, using a simple and low-cost technique as hydrothermal carbonization has a huge potential to add value to the production chain of babassu, a regional palm. In this work, two important waste biomasses, derived from babassu coconut, called mesocarp and babassu kernel bran have been used as precursors to produce structured carbonaceous materials via hydrothermal carbonization. The produced hydrochars (HTCS) were characterized and their fuel properties were evaluated. The highest heating value (HHV) revealed values of up to $24.83 \mathrm{MJ} / \mathrm{kg}$ for hydrochar from mesocarp and up to $28.91 \mathrm{MJ} / \mathrm{kg}$ for hydrochar from babassu kernel bran, showing an increase of $69 \%$ and $89 \%$ of energy yield, respectively, in comparison with the respective precursor waste biomass. Furthermore, the energy density of hydrochars has increased with increasing treatment temperature. The chemical analysis have shown that fuel efficiency of mesocarp hydrochars has improved, such as reduction of ash content, volatile matter and oxygen amount as well as increment of total carbon and fixed carbon content. The evolution of biomass carbonization, as determined by FT-IR and Raman measurements, showed that most carbohydrates and proteins were decomposed at above $160^{\circ} \mathrm{C}$. The aromaticity of hydrochars increased with increasing temperature taking into account considerable amounts of functional groups remained in the hydrochars after hydrothermal treatment.
\end{abstract}

Keywords: Babassu coconut biomass; solid fuels; hydrochar; energy properties; biomass carbonization.

\footnotetext{
* Universidade Federal do Ceará, Laboratório de Materiais Funcionais Avançados (LaMFA), Departamento de Física, P.O. Box 6030, CEP 60455-900, Fortaleza-CE, Brazil.

Mrubens.costa@ifpi.edu.br DOI: $\underline{10.21577 / 1984-6835.20190048}$
} 


\title{
Hydrothermal Carbonization of Waste Babassu Coconut Biomass for Solid Fuel Production
}

\author{
Rubens S. Costa, ${ }^{\mathrm{a}, \mathrm{b}, *}$ Laís H. S. Vieira, ${ }^{\mathrm{c}}$ Anupama Ghosh, ${ }^{\mathrm{d}}$ Ariane M. S. \\ Santos, ${ }^{d}$ Odair P. Ferreira, ${ }^{c}$ Bartolomeu C. Viana ${ }^{b, d}$

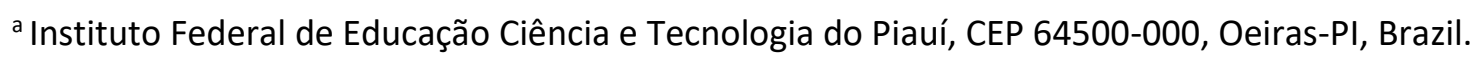 \\ b Universidade Federal do Piauí, Núcleo Interdisciplinar de Materiais Avançados, \\ Pós-Graduação em Ciência dos Materiais, CEP 64049-550, Teresina-PI, Brazil. \\ ' Universidade Federal do Ceará, Laboratório de Materiais Funcionais Avançados, \\ Departamento de Física, P.O. Box 6030, CEP 60455-900, Fortaleza-CE, Brazil. \\ dUniversidade Federal do Piauí, Laboratório de Física dos Materiais, Departamento de Física, \\ CEP 64049-550, Teresina-PI, Brazil. \\ * rubens.costa@ifpi.edu.br
}

Recebido em 7 de junho de 2018. Aceito para publicação em 13 de março de 2019

\section{Introduction}

\section{Experimental Section}

2.1. Pre-treatment of the raw materials

2.2. Hydrothermal carbonization of the mesocarp and babassu kernel bran

2.3. Characterization methods

\section{Results and Discussion}

3.1. Chemical analysis and yield of HTCS

3.2. Structural and morphological characterizations

\section{Conclusions}

\section{Introduction}

The pursuit of alternative sources for renewable and clean energy is a very important research field due to environment issues and finite fossil fuels reserves. Biomass feedstock, in general, has been an interesting candidate for biofuels, but the statistics demonstrated that only $10 \%$ of the global alternative renewable energy is generated from biomass. ${ }^{1,2}$ The abundance, sustainability and low cost of biomass wastes have promoted more attention and recognition of these wastes to be a $\mathrm{CO}_{2}$ neutral substitute of fossil fuels, in addition to reducing waste disposal in the environment, such as sulfur and nitrogen emissions. ${ }^{3,4}$ Biofuels generally offer many benefits, such as sustainability, greenhouse gas emissions reduction, regional development, especially in poorer regions where families survive from 
subsistence agriculture. ${ }^{5}$ All these facts highlight the importance of the development of technologies for a better use of biomass residues.

However, some properties of the biomass, such as high oxygen and moisture content are undesirable for the direct combustion and responsible for their low calorific value. ${ }^{6}$ The heterogeneous composition of the biomass makes it more complicated to obtain a specific product. Furthermore, the competition with food production is another issue to direct production of biomass for energy by combustion. The large-scale production of biomass involves high logistics costs due to low energy density of biomass. Thus, for biomass-based systems, a key challenge is to develop an efficient conversion technology which can also compete with conventional fossil fuels. ${ }^{7}$ Several environmental-friendly and eco-friendly techniques have been used to produce carbonaceous material from biomass that can be used as clean and renewable energy sources. Among these techniques, hydrothermal carbonization, a process where the biomass, suspended in water is subjected to relatively low temperatures $\left(130-250^{\circ} \mathrm{C}\right)$ in a closed system, during a residence time, generating a material of higher carbonaceous density and with differentiated properties called hydrothermal carbon (HTC) and these properties may vary depending on the synthesis parameters. Besides being more ecological, it presents advantages such as high carbon conversion yield, ease of handling, low technological cost, re-use of the by-product water and does not involve pollutants such as catalysts and / or surfactants. $^{8-11}$ The hydrothermal process provides a higher yield of product with higher energy efficiency, higher carbon content, more surface chemical groups, and lower ash content compared with solid fuel produced by pyrolysis. ${ }^{2,12,13}$

Babassu (Orbignya sp.) is a native palm tree from Brazil and its area of concentration is the state of Maranhão and Piauí (northeastern states of Brazil), with almost 10 million hectares with a very high average density of 200 trees/hectare. The weight of the fruit varies between $90-280 \mathrm{~g}$ and the nuts production is about 90.000 ton/years ${ }^{14-16}$.

As shown in Figure 1, the babassu's fruit generally known as the babassu coconut, consists mainly of four parts, namely: epicarp, the external fibrous part ( $11 \%$ of the total weight of the fruit);endocarp, hard wooden inner part ( $59 \%$ of the total weight of the fruit); mesocarp, a layer of starch-rich granulous part located between the epicarp and endocarp, ( $23 \%$ of the total weight of the fruit); and the kernels ( $7 \%$ of the total weight of the fruit) rich in oil with great commercial interest (food, cleaners and cosmetics products). ${ }^{17,18}$ The different compositions and properties of these four parts makes this fruit a potential candidate for the supply chain of Brazilian biomass extraction plant, with diverse socio-economic activities involving a large number of families, living from the extraction of various parts of babassu coconut, as well as the industries based on the exploration of production of useful materials from this plant species. ${ }^{19}$ The kernel oil and mesocarp can be used to produce biofuels. ${ }^{20,21}$ Epicarp, mesocarp, and endocarp have a relevant potential for coal, fuel gas and oil, starch, and ethanol production. ${ }^{16,21}$ The mesocarp mainly consists of starch (60\%) with considerable amount of fiber (10\%) and it is rich in glycerin, phosphoric acid and choline and gives a flour which can also be used as food for humans and animals, ${ }^{22,} 23$ but its composition varies as a function of its origin. ${ }^{21}$ In the oil extraction process from the babassu nuts, an amount of residue is generated from the pressing process of the kernel, a cake-like residue, and the solvent extraction of the residual oil present in the cake, known as bran. Both cake and babassu brans are fibrous with low percentage of lignin (around $3 \%$ ), along with $17 \%$ of protein and $26 \%$ of fiber, it can be useful for animal feed complement. ${ }^{24-}$ ${ }^{26}$ The properties of mesocarp and kernel bran as a feedstock for energy production still remain little explored in the literature. 


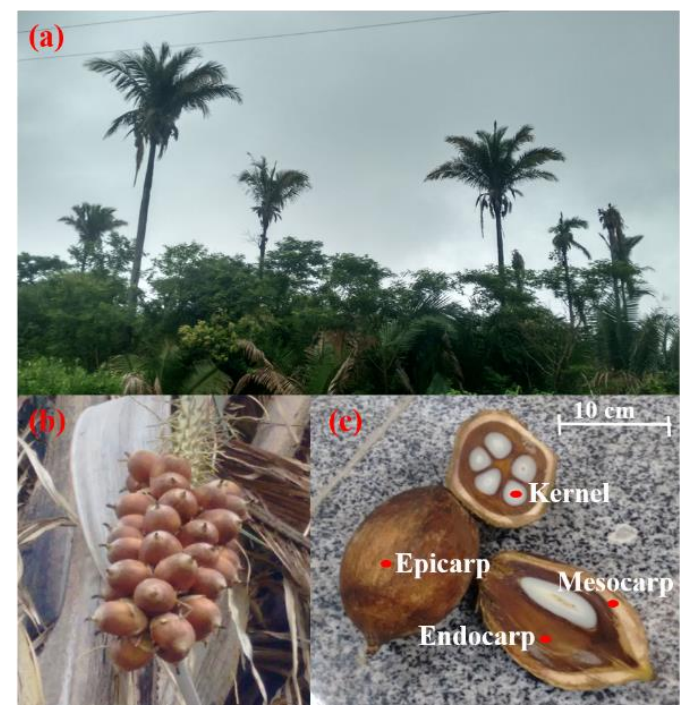

Figure 1. Images of physical characteristics of babassu coconut: Babassu palm (a); Babassu bunches (b); babassu fruit (c) and parts of babassu coconut (adapted from Ghosh et al., 2019) ${ }^{27}$

Although there are several scientific papers regarding the constituents of the babassu coconut and its potential applications, to the best of our knowledgement there are no reports of the production of carbonaceous materials from these constituent parts of coco babassu using hydrothermal carbonization in order to obtain a solid fuel. Thus, in the present study, the main objective is to investigate the potential of the babassu mesocarp and babassu kernel bran as feedstock to obtain solid fuel using hydrothermal carbonization (at moderate temperatures) and the combustion and energy properties have been predicted in order to evaluate the feasibility of the HTCS from Babassu byproducts for solid fuel applications. Furthermore, as secondary objectives, its physicochemical, morphological and structural properties will also be characterized.

\section{Experimental Section}

\subsection{Pretreatment of the raw materials}

Two by-products of the babassu production chain were used for hydrothermal carbonization and production of solid fuel: babassu kernel bran and mesocarp. The samples were purchased from Babcoall company, Teresina-Piauí-Brazil. Both the feedstocks were sieved in order to obtain particles with size $<2500 \mu \mathrm{m}$. No pretreatment was performed with the mesocarp. The babassu kernel bran was obtained by washing the babassu cake with solvent in a proportion of hexane/cake $(3: 1 \mathrm{w} / \mathrm{w})$ for 90 min under mechanical stirring to remove the residual oil present in the babassu cake. Then the bran was filtered and vacuum dried at room temperature.

\subsection{Hydrothermal carbonization mesocarp and babassu kernel bran}

The raw materials were suspended in water in a ratio of $10 \%(\mathrm{w} / \mathrm{w})$ and stirred for 30 min using a magnetic stirrer. The mixture was then transferred to a Teflon container, and inserted into a stainless steel reactor (autoclave). The reactor was closed and placed in a muffle furnace. The synthesis parameters varied as follows: temperature of 120,160 and $180^{\circ} \mathrm{C}$ (all temperatures with tolerance $\pm 5^{\circ} \mathrm{C}$ ); residence time of $48 \mathrm{~h}$, and $\mathrm{pH}$ of 3.0 and 6.0, adjusted by addition of concentrated $\mathrm{H}_{2} \mathrm{SO}_{4}$. 
After carbonization, the products were filtered and washed with distilled water until neutral $\mathrm{pH}$, then they were dried in oven until constant mass. The nomenclatures used were: mesocarp, babassu kernel bran for feedstocks, $\mathrm{MC}=$ mesocarp $\mathrm{HTC}, \mathrm{BC}=$ Babassu kernel bran $\mathrm{HTC}$, following by the residence temperature in minutes and initial pH of the synthesis.

\subsection{Characterization methods}

Elemental analysis of carbon, hydrogen, nitrogen and sulfur was carried out in the Equipment Fisons, model EA1108 CHNS-O, with Helium as the carrier gas with a flow of $120 \mathrm{ml} / \mathrm{min}$, at $1020{ }^{\circ} \mathrm{C}$. The oxygen content was calculated by the following equation: $0 \%$ $=100-(\mathrm{C} \%+\mathrm{H} \%+\mathrm{S} \%+\mathrm{N} \%+$ ash\%). For thermogravimetric analysis, the pieces of equipment used were NETZSCH STA 449F3 and SDT Q600 TA instrument, the temperature ranged from 25 to $800{ }^{\circ} \mathrm{C}$, with a heating rate $10^{\circ} \mathrm{C} / \mathrm{min}$ under gas flow of 20 $\mathrm{mL} / \mathrm{min}$. In the pyrolysis experiments Argon inert atmospheres were used, and in the combustion experiments synthetic air atmospheres were used. The volatile matter and ash were obtained with the TGA data (shown in the S.I.) according to the method used by Silva Filho. ${ }^{28}$ The temperatures at which the volatile matter (VM) decomposition occurred ranged from 350 to $380^{\circ} \mathrm{C}$ for all the samples according to the TGA curves (Figures S3 and S4 of the supplementary material). The fixed carbon (FC) content was calculated by difference using the equation: $\% \mathrm{FC}=100-(\%$ ash +\% VM). ${ }^{6,29}$ The ATR (Attenuated total reflectance) Infrared (FTIR) measurements were carried out in a Bruker spectrometer, model Vertex 70 with resolution of $4 \mathrm{~cm}^{-1}$ and 64 scans/min. Raman spectroscopy was carried out using a Bruker Senterra spectrometer attached with a confocal microscope and a green laser of $532 \mathrm{~nm}$ of wavelength as excitation. SEM images were carried out using a Quanta 250FEG from FEI company. The heat capacity measurements (HHV) were performed using an oxygen bomb calorimeter, Parr, model 6400. The energy densification (ED) was determined by the energy content of the hydrochar divided by the energy the crude biomass content. The energy yield (EY) was defined as the production of hydrochar multiplied by energy densification. HHV, ED and EY were performed for both HTCs and precursor materials, as well, in order to infer about the efficiency of the carbonization and thereby the potentiality of application as a solid fuel.

\section{Results and Discussion}

\subsection{Chemical analysis and yield of HTCs}

The elemental composition was affected by the parameters of HTC reactions, as shown in Table 1. As expected, the carbon content has increased and the oxygen content has decreased, sharply, with the increase of temperature for the HTC. An increase of the carbon content and decrease of the oxygen could lead to the improvement of combustion properties of HTC. The HTC yield did not decrease when temperature was increased, in the range of hydrothermal treatment used up to $180{ }^{\circ} \mathrm{C}$, reaching $35.9 \%$ and $78.2 \%$ for mesocarp and kernel bran, respectively (see supplementary material). Similar trends of temperature vs. hydrochar yield were observed for both samples at different $\mathrm{pHs}$.

The Van Krevelen diagram ${ }^{30}$ constructed from the data of Table 1 and shown in Figure 2 , allows a more detailed analysis of the degree of HTCs carbonization by evaluating the $\mathrm{H} / \mathrm{C}$ and $\mathrm{O} / \mathrm{C}$ atomic ratios, which changes from the starting materials during the hydrothermal carbonization due to dehydration and decarboxylation processes..$^{31,32}$ 
Table 1. Proximate analysis, ultimate analysis and higher heating value of mesocarp, babassu kernel bran and their derived-hydrochars

\begin{tabular}{|c|c|c|c|c|c|c|c|c|c|c|c|}
\hline Sample & VM(\%) & *Ash(\%) & $\mathrm{FC}(\%)$ & C (\%) & H (\%) & $\mathbf{N}(\%)$ & S (\%) & $\mathrm{O}^{\mathrm{a}}(\%)$ & $\begin{array}{l}\text { HHV } \\
\text { (MJ/Kg) }\end{array}$ & ED & EY(\%) \\
\hline Mesocarp & 70.1 & 6.5 & 23.4 & 39.2 & 6.4 & 0 & 0 & 47.9 & 12.72 & -- & -- \\
\hline MC-120/3 & 52.0 & 9.7 & 38.3 & 49.9 & 5.4 & 1.7 & 0.3 & 33 & 19.15 & 1.50 & 32.88 \\
\hline MC-120/6 & 77.8 & 5.7 & 16.5 & 41.9 & 6.1 & 0.1 & 0.0 & 46.2 & 15.62 & 1.23 & 31.27 \\
\hline MC-160/3 & 36.5 & 3.5 & 60 & 65.3 & 4.6 & $8.9 .10^{-2}$ & 0.0 & 26.6 & 24.09 & 1.89 & 65.03 \\
\hline MC-160/6 & 39.2 & 4.7 & 56.1 & 63.5 & 3.9 & 0.1 & 0.0 & 27.8 & 23.26 & 1.83 & 65.37 \\
\hline MC-180/3 & 33.1 & 5.7 & 61.2 & 67.2 & 4.3 & $4 \cdot 0.10^{-2}$ & 0.0 & 22.8 & 24.83 & 1.95 & 55.89 \\
\hline MC-180/6 & 34.6 & 4.7 & 60.7 & 65.4 & 3.7 & 0.3 & 0.0 & 25.9 & 24.25 & 1.91 & 68.70 \\
\hline B.K. bran & 62.6 & 11.8 & 25.6 & 46.9 & 8.5 & 7.8 & 0.4 & 24.6 & 22.15 & -- & -- \\
\hline BC-120/3 & 69.5 & 8.8 & 21.7 & 61.0 & 12.3 & 4.7 & 0.4 & 12.8 & 28.84 & 1.30 & 36.99 \\
\hline BC-120/6 & 67.5 & 10.8 & 21.7 & 60.8 & 11.8 & 4.6 & 0.4 & 11.6 & 22.99 & 1.04 & 68.46 \\
\hline BC-160/3 & 62.4 & 11.8 & 25.6 & 60.1 & 9.4 & 3.4 & 0.4 & 14.9 & 27.99 & 1.26 & 38.08 \\
\hline BC-160/6 & 42.7 & 19.8 & 37.5 & 51.5 & 6.1 & 4.3 & 0.4 & 17.9 & 23.28 & 1.05 & 67.94 \\
\hline BC-180/3 & 38.5 & 15.7 & 45.8 & 63.7 & 9.9 & 4.2 & 0.3 & 6.2 & 28.91 & 1.30 & 41.26 \\
\hline BC-180/6 & 35.0 & 17.1 & 47.9 & 58.3 & 8.1 & 4.5 & 0.3 & 11.7 & 25.23 & 1.14 & 89.16 \\
\hline
\end{tabular}

B. . bran = Babassu kernel bran; VM = volatile matter; Ash = Ash content; $\mathrm{FC}=$ fixed carbon; $\mathrm{C}=\mathrm{Carbon}$ content; $\mathrm{H}=\mathrm{Hydrogen}$ content; $\mathrm{N}=\mathrm{Nitrogen}$ content; $\mathrm{S}=$ Sulfur content $\mathrm{O}=$ Oxygen content; $\mathrm{HHV}=$ Higher heating value; $\mathrm{ED}=$ energy densification; $\mathrm{EY}=$ energy yield .

${ }^{a}$ Calculated by difference of elements

*Calculated from TGA measurements in synthetic air atmosphere 


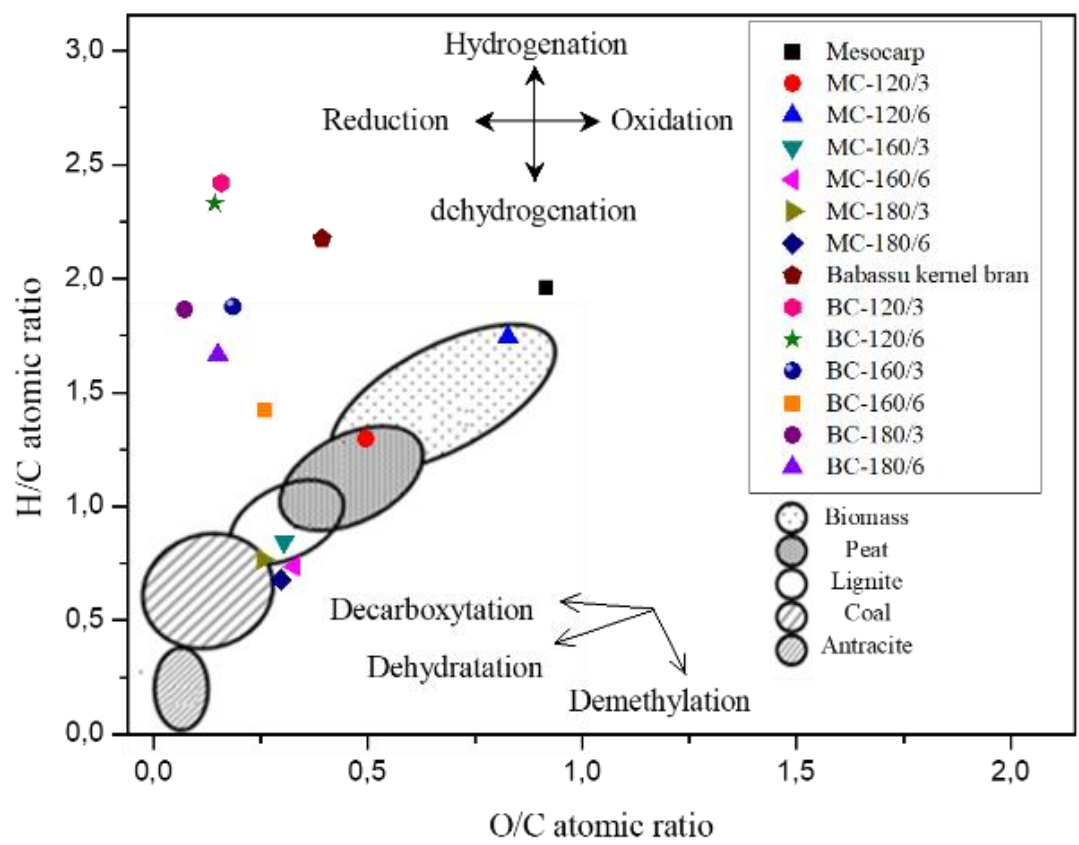

Figure 2. Van Krevelen diagram of HTCs derived from mesocarp and babassu kernel bran along with the precursors

For HTC obtained from mesocarp, it is possible to observe that the samples carbonized at $\mathrm{pH} 3.0$ have higher carbon content than the samples at $\mathrm{pH} 6.0$ with the same temperature parameters, suggesting that low $\mathrm{pH}$ promotes a better carbonization. The $\mathrm{H} / \mathrm{C}$ and $\mathrm{O} / \mathrm{C}$ ratios decreased as the temperatures increased. Even for the HTC obtained at relatively low temperature of $120^{\circ} \mathrm{C}$, the values were lower than those of raw mesocarp. Low $\mathrm{H} / \mathrm{C}$ and $\mathrm{O} / \mathrm{C}$ ratios are favorable, because of the reduced water vapor, smoke and energy loss during the combustion process. $^{6}$ Thus, due to the decrease of the low energy $\mathrm{H}-\mathrm{C}$ and $\mathrm{O}-\mathrm{C}$ bonds and increase of high energy $\mathrm{C}-\mathrm{C}$ bond, the mesocarp energy density improved to a large extent, as indicated by the HHV and ED in the Table 1.

The fixed carbon content was determined by TGA analysis (Table 1) and it is an important factor in the combustion behavior, as well as the volatile matter that can affect the combustion yield. Ash contents (for most samples with values similar to bituminous coal $(1-10 \%),{ }^{33}$ is another important parameter, due to transport costs, handling and process management, besides influencing the corrosion and slag formation. ${ }^{33}$ The results show low ash contents and volatile organic matter and higher fixed carbon contents in most of the mesocarp HTCs than in the precursor, corroborating with HHV values, ED and energy yield (EY). As shown in Table 1, the energy densification is increased as the temperature increased, from 1.50 to 1.95 at $180^{\circ} \mathrm{C}$ and $\mathrm{pH} 3$. The highest $\mathrm{EY}$ was obtained at $180^{\circ} \mathrm{C}$ and $\mathrm{pH} 6$, reaching $68.70 \%$ and there is a trend with the increment of temperature.

Among the HTCs obtained from babassu kernel bran the sample BC- $180 / 3$ seems to have the highest carbon content, at around $64 \%$ while the fixed carbon (FC) content is about $48 \%$ for feedstock. The $\mathrm{O} / \mathrm{C}$ ratio has decreased in HTCs from kernel bran, however, there is no trend of the $\mathrm{O} / \mathrm{C}$ decrease with the increase of temperature. Furthermore, The $\mathrm{H} / \mathrm{C}$ ratio has not decreased in most of the HTCs. Both HTCs originated from the babassu kernel were located more to the left and above in the Van Krevelen diagram than the mesocarp HTCs, because they have lower percentages of oxygen and higher hydrogen contents than mesocarp HTCs.

The $\mathrm{H} / \mathrm{C}$ and $\mathrm{O} / \mathrm{C}$ ratios are greater in these two samples than BC-180/3, which suggests that these two samples have undergone more dehydrogenation than BC-180/3 during the 
carbonization process. Generally, lower O/C and $\mathrm{H} / \mathrm{C}$ are necessary to have a good quality for fuel ${ }^{6}$. Ash contents did not have a trend with temperature, but they remained at relatively interesting levels (lower than $17 \%$ ). 6,27,28,32 The HHV and ED increased after the hydrothermal treatment, but the increment is very little, almost constant and there is no trend with increment of temperature. It is noted that $\mathrm{EY}$ is better at higher $\mathrm{pH}$, however, there is a trend with increment of temperature. The best results were obtained for samples BC- $120 / 6$ and BC160-6 with $68 \%$, and BC-180/6 with $89 \%$, approximately.

The HHV results for all the samples are summarized in Table 1, which shows that for HTCs from mesocarp, HHV was increased as compared to the precursor at higher temperature improving the HHV from 12.7 $\mathrm{MJ} / \mathrm{kg}$ (mesocarp) to $24.8 \mathrm{MJ} / \mathrm{kg}$ (MC-180/3) which is slightly higher than the coal (wet basis - $23.97 \mathrm{MJ}^{\mathrm{Kg}}{ }^{-1}$ ) and close to the HHV of coking coal (wet basis - $\left.29.86 \mathrm{MJ}^{\mathrm{Kg}}{ }^{-1}\right)^{33}$. Furthermore, the HHV increment is higher in the case of mesocarp-derived HTCs and it is not very significant in the case of kernel branderived HTCs. The HHV of all HTCs produced showed to be dependent on reaction temperature and $\mathrm{pH}$. At low $\mathrm{pH}, \mathrm{HHV}$ of the samples were higher than the samples produced at the same temperature and higher $\mathrm{pH}$. It is observed that low $\mathrm{pH}$ is more efficient to increase the $\mathrm{HHV}$ at all temperatures.

The fixed carbon content has a decisive influence on the energy densification of materials produced with low ash-content, such as HTCs obtained from babassu mesocarp, in which the highest FC values resulted in a higher energy densification, which did not happen for the hydrothermal carbons obtained from babassu kernel bran which has higher ash-content.

In addition to energy densification (ED), the energy yield of the produced hydrochars were also evaluated in the present study and it showed slightly more interesting values with the increase of the carbonization temperature as well as for the hydrochars obtained from the mesocarp in detriment to the babassu kernel bran, in addition to presenting smaller ash, important data for solid fuels. The different hydrothermal conditions and the different starting babassu feedstocks could explain these results.

The results of elemental analysis corroborate with the results found in the thermal analysis for all the HTCs, in general. Table 2 summarizes the results of the thermal analysis under argon atmosphere, which can be divided into three different temperature ranges, the interval (1) between 25 and $150{ }^{\circ} \mathrm{C}$, attributing to elimination of adsorbed water, (2) in the range $150-450{ }^{\circ} \mathrm{C}$, mostly due to the elimination of structural water and (3) above $450{ }^{\circ} \mathrm{C}$, due to loss of the organic moieties present in the sample. It can be seen that most HTCs carbonized at lower temperatures have has a lower degree of carbonization than the HTCs carbonized at higher temperatures and it can be related to the loss of structural water occurred in the range from 150 and $450{ }^{\circ} \mathrm{C}$. However, the mass losses due to the structural water in the samples MC-120/6, BC-120/3, BC$120 / 6$ and $B C-160 / 3$ are slightly larger than the precursor itself, which suggests a higher amount of water into the samples. 
Table 2. Percentage mass loss in different temperature ranges for the precursors and derived HTCs

\begin{tabular}{|c|c|c|c|c|c|c|c|}
\hline \multicolumn{8}{|c|}{ Mass loss (\%) } \\
\hline & Mesocarp & MC-120/3 & MC-120/6 & MC-160/3 & MC-160/6 & MC-180/3 & MC-180/6 \\
\hline $25-150^{\circ} \mathrm{C}$ & 3.31 & 2.81 & 3.62 & 2.18 & 1.75 & 2.60 & 1.30 \\
\hline $150-450^{\circ} \mathrm{C}$ & 78.59 & 55.01 & 81.11 & 27.66 & 28.31 & 26.19 & 24.13 \\
\hline$>450^{\circ} \mathrm{C}$ & 3.91 & 7.90 & 4.01 & 14.75 & 13.78 & 17.49 & 15.76 \\
\hline \multirow[t]{2}{*}{ Final mass (\%) } & 14.19 & 34.28 & 11.26 & 55.41 & 56.16 & 53.72 & 58.81 \\
\hline & B.K. Bran & $B C-120 / 3$ & BC $-120 / 6$ & BC $-160 / 3$ & BC $-160 / 6$ & BC-180/3 & BC $-180 / 6$ \\
\hline $25-150^{\circ} \mathrm{C}$ & 3.90 & 1.33 & 3.04 & 2.60 & 1.32 & 1.73 & 1.95 \\
\hline $150-450^{\circ} \mathrm{C}$ & 64.36 & 79.89 & 76.49 & 67.11 & 51.58 & 54.71 & 52.59 \\
\hline$>450^{\circ} \mathrm{C}$ & 5.80 & 4.89 & 4.84 & 6.52 & 8.32 & 7.78 & 8.75 \\
\hline Final mass (\%) & 25.94 & 13.89 & 15.63 & 23.77 & 38.78 & 35.78 & 36.71 \\
\hline
\end{tabular}

Calculated from TGA measurements in argon atmosphere 
The results discussed so far show that the combustion properties of HTCs were improved regarding the biomass precursor, mainly in the mesocarp HTCs. Mesocarp HTCs have decreased oxygen, volatile matter and ash contents and increased value of carboncontent, HHV and EY. In HTCs from kernel bran, the HHV and EY were satisfactory, the volatile matter and oxygen content have decreased and carbon content has increased. The HTCs from both the precursors have potential to be a solid fuel for direct combustion or cocombustion with another solid fuel. However, due to its lower nitrogen and sulfur contents, the mesocarp seems to be a more suitable candidate than kernel bran as biomass feedstock for solid fuel production. On the other hand, the HTC production yield from kernel bran is higher than mesocarp.

\subsection{Structural and morphological} characterizations

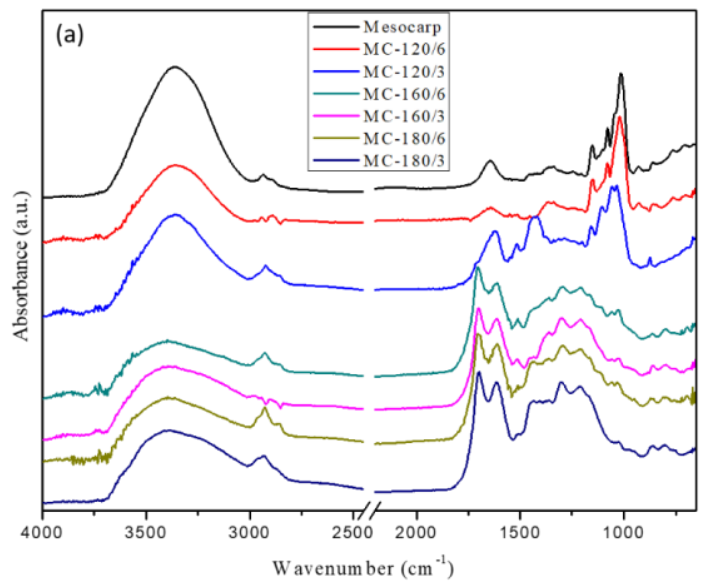

The FTIR spectra of HTCs obtained from mesocarp (a)and babassu kernel bran(b) are shown in Figure 3 , and the presence of functional groups were analyzed. The FTIR spectra of Figure $3(\mathrm{a})$ show a broad band at around $3400 \mathrm{~cm}^{-1}$ which can be attributed to the hydroxyl groups present in the compounds of the structure of starch, the major constituent of mesocarp, and water. However, the intensities of these bands have been reduced with increasing temperature confirming the dehydration reactions. The band at around $2900 \mathrm{~cm}^{-1}$ is related to the $\mathrm{C}-\mathrm{H}$ bond vibration of groups like $-\mathrm{CH}_{2}$ and $-\mathrm{CH}_{3}$. Also, these materials show IR bands at around $1200-950 \mathrm{~cm}^{-1}$, which indicates the presence of $\mathrm{C}-\mathrm{O}-\mathrm{C}$ bonds from the glycosidic rings in the starch chains ${ }^{34}$. The reduction in the intensities of these bands in the HTCs suggest that there was the breaking of $\mathrm{C}-\mathrm{O}$ linkages of long starch chains and deoxygenation in the carbonization process and thereby decreasing of the crystallinity of the material, which was confirmed by XRD (Supplementary Figure S1).

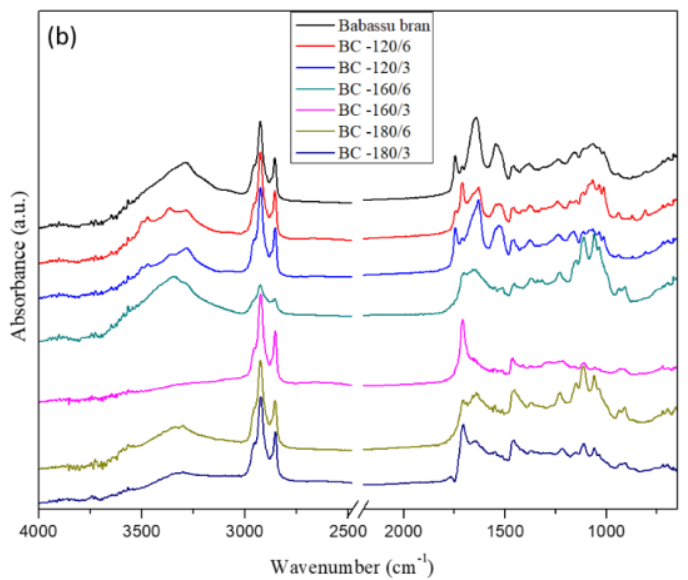

Figure 3. FTIR spectra of HTCs derived from mesocarp (a) and babassu kernel bran (b) along with the precursors

The mesocarp HTCs obtained at $160^{\circ} \mathrm{C}$ and $180^{\circ} \mathrm{C}$ shows higher intensity of the band at $1618 \mathrm{~cm}^{-1}$, assigned to $\mathrm{C}=\mathrm{C}$ linkage, suggesting better dehydrogenation and/or deoxygenation of these materials during the hydrothermal carbonization and the aromatic moities formation. The band around $1703 \mathrm{~cm}^{-}$
1 , is associated with the $\mathrm{C}=\mathrm{O}$ group, and appears in HTCs which may indicate the divisions of glycosidic rings in the starch chains generating the aliphatic chain structures which is also confirmed by the reduction of the band intensity around $1145 \mathrm{~cm}^{-1}$, characteristic of cyclic sugars. ${ }^{35}$ The breaking 
of the starch structure is an important factor in the process of nucleation in the carbonization to generate the carbon spheres which are shown in the SEM images (Figure 5) and causes the loss of degree of crystallinity with the generation of amorphous regions. ${ }^{36-}$ 37

For the babassu kernel bran and the HTCS derived from kernel bran, the FTIR presented in Figure 3(b) shows broad and low intense bands in the region from $3630-3045 \mathrm{~cm}^{-1}$, related to stretching of $-\mathrm{OH}$ and $\mathrm{N}-\mathrm{H}$ bonds. Probably these $\mathrm{N}-\mathrm{H}$ bands are originated from the protein constituents of babassu kernel bran. A very intense band at $1645 \mathrm{~cm}^{-1}$ and the other band at $1541 \mathrm{~cm}^{-1}$ in the pure babassu kernel bran can be related to the $\mathrm{H}-\mathrm{O}-\mathrm{H}$ and $\mathrm{N}$ $\mathrm{H}$ deformation of the adsorbed water and amide bonds from proteins present in babassu kernel bran. These bands undergo considerable reduction when this raw material is carbonized at $160{ }^{\circ} \mathrm{C}$ and $180{ }^{\circ} \mathrm{C}$, suggesting the water release and protein degradation in the hydrothermal process at higher temperatures ${ }^{38,39}$. The decrease of $-\mathrm{OH}$ groups with the increase of carbonization temperature promotes an increase in hydrophobicity of HTC compared to precursor biomass and it is important for handling and storage of the solid fuel affording resistance to humidity.

The carbonaceous materials usually shows two bands in the Raman spectrum that can give an idea about the degree of graphitization of the hydrothermal carbon produced: the first, the $G$ band $\left(1560 \mathrm{~cm}^{-1}\right)$, in-plane vibration of graphitic carbon with $\mathrm{sp}^{2}$ hybridization, and second, the $D$ band $\left(1360 \mathrm{~cm}^{-1}\right)$, the defect or disorder related band, which is associated to $\mathrm{sp}^{3}$ hybridization of carbon-carbon bonds ${ }^{40,41}$. Figure 4 shows Raman spectra of the HTCs derived from mesocarp at higher temperatures. The broad profile of $D$ band at around $1336 \mathrm{~cm}^{-1}$ and $\mathrm{G}$ band at around 1592 $\mathrm{cm}^{-1}$ indicate that the carbonized materials are mostly composed of amorphous structure. It was not possible to obtain Raman signal of babassu kernel bran derived HTCs, as well as HTCs formed from low-temperature carbonization of mesocarp $\left(120^{\circ} \mathrm{C}\right)$, because there is an interference of the luminescence phenomena over the Raman spectra originating from non-carbonized organic compounds present in those samples.

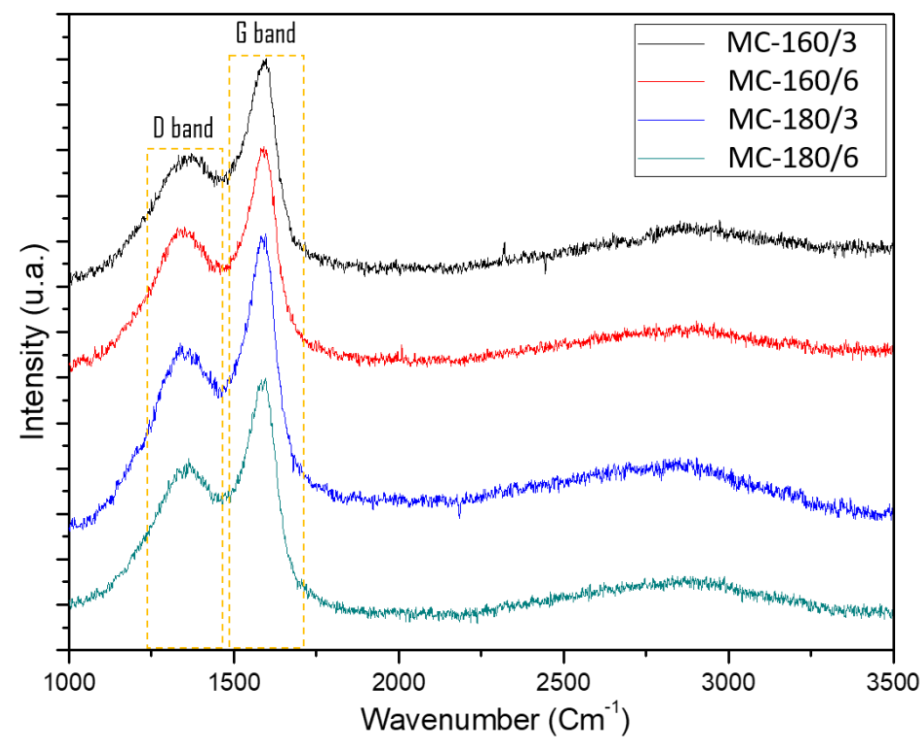

Figure 4. Raman spectra of the samples from mesocarp carbonized which did not exhibit luminescence signal 
In Figure 5, the SEM images of mesocarpderived HTCs shows the formation of carbon spheres, probably these spheres follow similar formation mechanism described by Sevilla and Fuertes $^{35}$ and Ryu et al. (1990). ${ }^{41}$ The agglomerates resemble grape bunches which may be due to the presence of terminal $\mathrm{sp}^{2}$ hybridized carbon with unpaired electron helping to join the carbon spheres to produce similar grape-brunch structures as suggested by Ballesteros ${ }^{42}$. It can be observed from these SEM images, that the spheres have a uniform size distribution in each sample. It has also been observed that the average diameter of the spheres formed in higher temperature $\left(180^{\circ} \mathrm{C}\right)$ is larger in size $(4-17 \mu \mathrm{m})$, whereas in the HTCs formed in lower temperature $\left(160{ }^{\circ} \mathrm{C}\right)$ the average diameter of the spheres is smaller $(0.2 \mu \mathrm{m}-1.7 \mu \mathrm{m})$.

Figure 6 represents the SEM images of the HTCs formed from carbonization of babassu kernel bran, which shows the presence of irregular plates and agglomerates of different sizes, probably due to the fact that kernel bran is mainly composed of fibers and proteins of diverse complex structures. However, occasional presence of carbon sphere similar to those obtained in the case of mesocarpderived HTCs are observed, probably due to the carbonization of traces of polysaccharide material present in the babassu kernel bran. ${ }^{43}$

d)

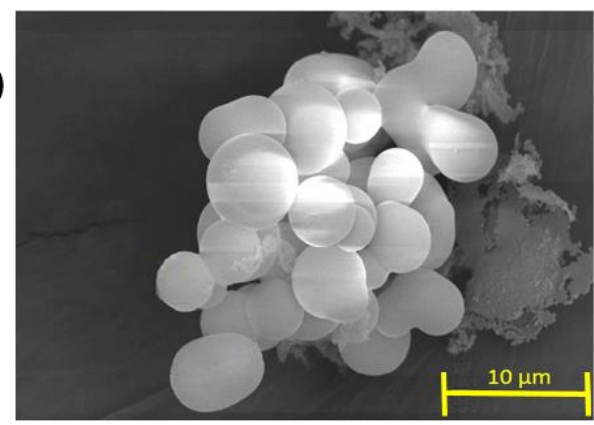

(b)

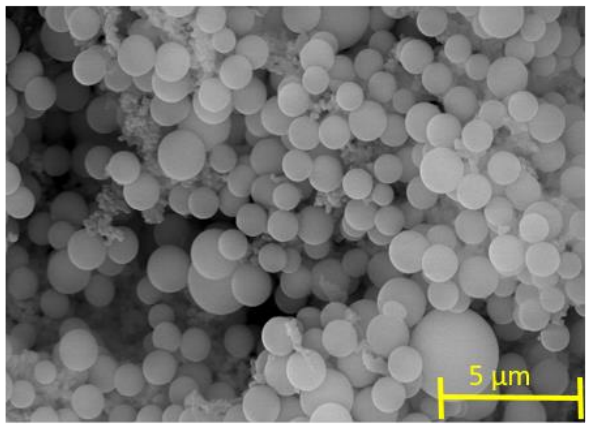

(c)

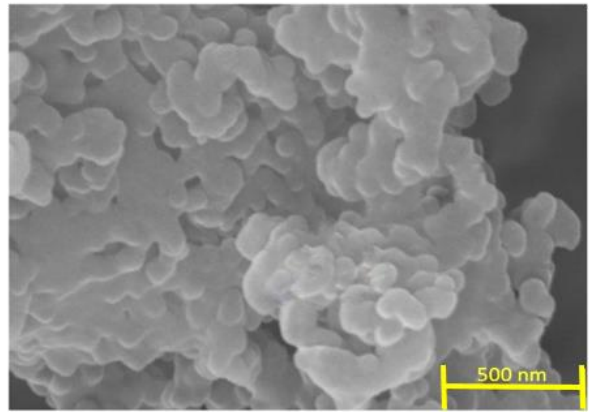

(e)

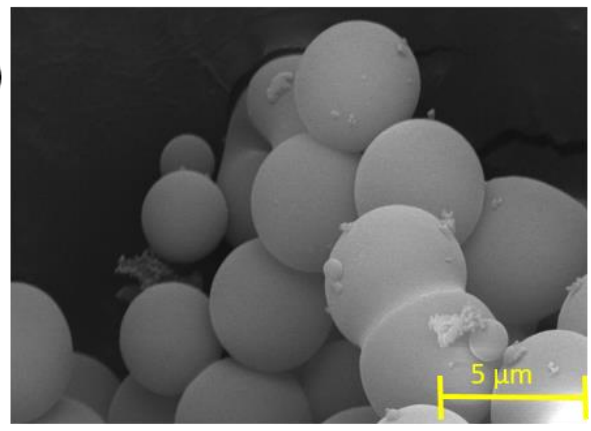

(f)

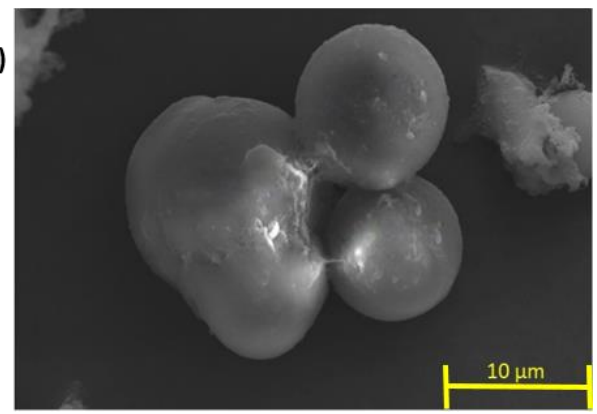

Figure 5. SEM images (a) of MC-160/3; (b) and (c) of MC-160/6; (d) of MC-180/3 and (e) and (f) of MC- $180 / 6$ 
(a)

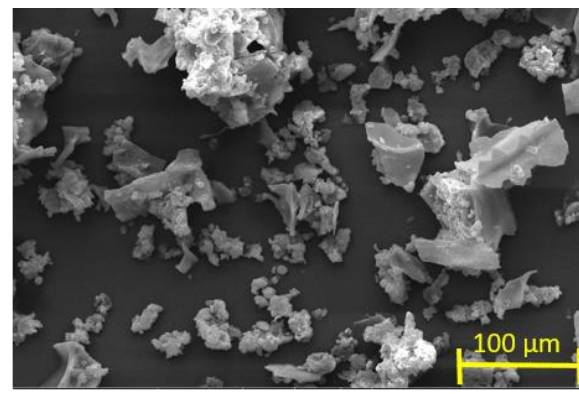

(b)

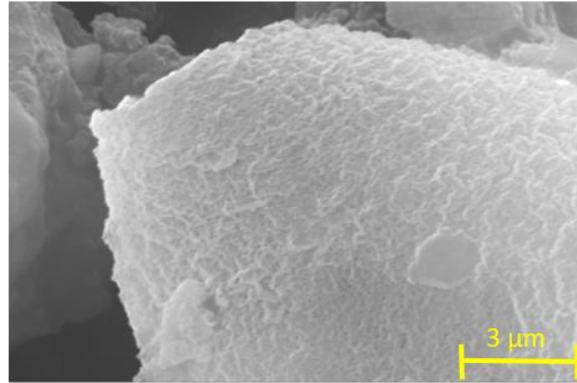

(c)

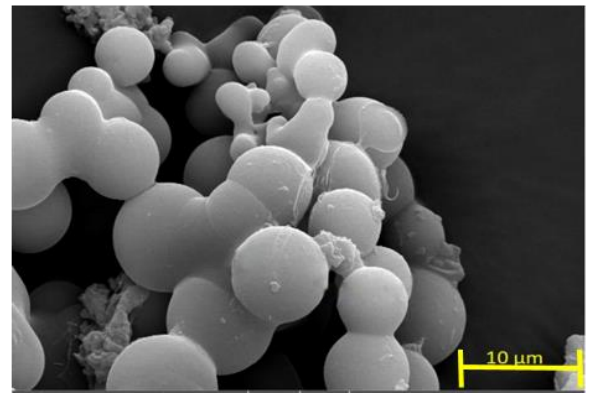

(d)

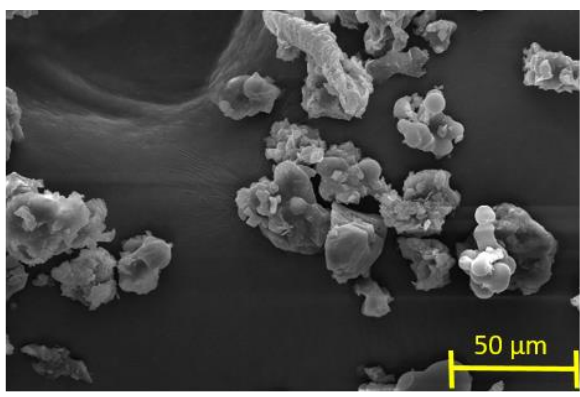

(e)

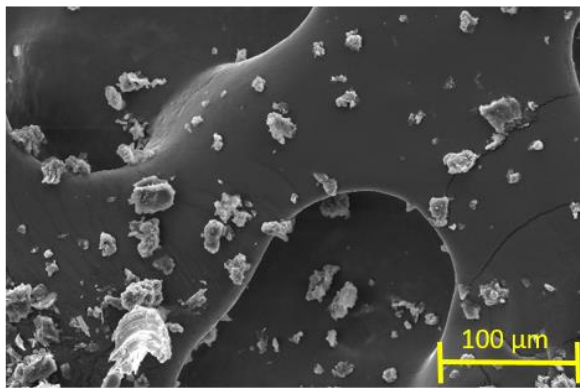

(f)

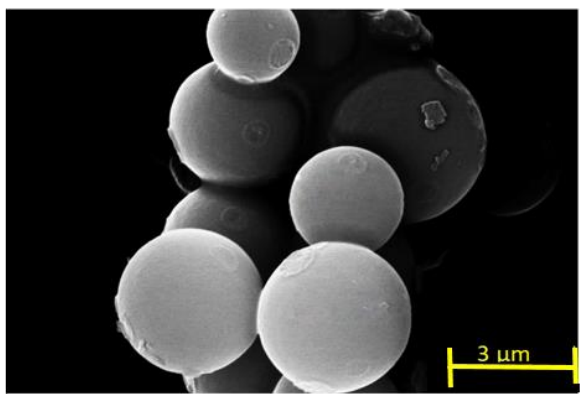

Figure 6. SEM images (a) and (b) of FC-120/48/6; (c) of FC-160/48/3; (d) of FC-160/48/6 and (e) and (f) of FC-180/48 /6

\section{Conclusions}

The hydrothermal carbonization was successfully utilized for production of solid fuels from babassu waste biomass. It has been observed that the fuel qualities of the HTCs improved compared to their respective precursor babassu biomass, with very low sulfur content, decreased oxygen, volatile matter and ash contents (most of HTCs), and also increased carbon and fixed carbon content.

As for the biomass feedstock for solid fuel production, babassu mesocarp seems to be more suitable than kernel bran, due to its lower nitrogen, sulfur and ash contents. Also, HTCs with improved fuel qualities were produced and the HHV reached $24.83 \mathrm{MJ} / \mathrm{kg}$ for the mesocarp and up to $28.81 \mathrm{MJ} / \mathrm{kg}$ for the babassu kernel bran, and energy yield values of up to $68 \%$ for carbonized mesocarp and up to $89 \%$ for babassu kernel bran (very significant increment at lower temperatures than usual temperatures in pyrolysis).

Henceforth, it was possible through a hydrotermal process to convert a low carbon feedstock into a product with high carboncontent and high calorific value, improving the solid fuel quality. Thus, the HTCs produced from babassu parts may be a promising alternative for production of solid fuels for either direct combustion or co-combustion with another fuel, because of their lower production temperatures (120-180 $\mathrm{C})$, higher hidrophobicity and improved fuel qualities. 


\section{Ackowledgements}

The authors are grateful to Central Analítica-UFC/CTINFRA/MCTI-SISNANO/Pró-

Equipamentos CAPES for providing the electron scanning microscopes as well as we thank Professor Marcos Jacome de Araujo from UFPI, for the HHV measurements. This work was supported by CNPq (Grant 478743/2013-0), FUNCAP (PRONEX PR2-010100006.01.00/15) and CAPES (PROCAD 2013 Grant 183995).

\section{References}

${ }^{1}$ I. E. A. Key World Energy Statistics 2014. International Energy Agency2014. [Link]

${ }^{2}$ Nizamuddin, S.; Jaya Kumar, N. S.; Sahu, J. N.; Ganesan, P.; Mubarak, N. M.; Mazari, S. A. Synthesis and Characterization of Hydrochars Produced by Hydrothermal Carbonization of Oil Palm Shell. The Canadian Journal of Chemical Engineering 2015, 93,1916. [CrossRef]

${ }^{3}$ Nizamuddin, S.; Jayakumar, N. S.; Sahu, J. N.; Ganesan, P.; Bhutto, A. W.; Mubarak, N. M. Hydrothermal Carbonization of Oil Palm Shell. Korean Journal of Chemical Engineering 2015, 32, 1789. [CrossRef]

${ }^{4}$ Missaoui, A.; Bostyn, S.; Belandria, V.; Cagnon, B.; Sarh, B.; Gökalp, I. Hydrothermal Carbonization of Dried Olive Pomace: Energy Potential and Process Performances. Journal of Analytical and Applied Pyrolysis 2017, 128, 281. [CrossRef]

${ }^{5}$ Ben-Iwo, J.; Manovic, V.; Longhurst, P. Biomass Resources and Biofuels Potential for the Production of Transportation Fuels in Nigeria. Renewable and Sustainable Energy Reviews 2016, 63, 172.[CrossRef]

${ }^{6}$ Liu, Z.; Quek, A.; Kent Hoekman, S.; Balasubramanian, R. Production of Solid Biochar Fuel from Waste Biomass by Hydrothermal Carbonization. Fuel 2013, 103, 943. [CrossRef]
7 Popp, J.; Lakner, Z.; Harangi-Rákos, M.; Fári, $M$. The Effect of Bioenergy Expansion: Food, Energy, and Environment. Renewable and Sustainable Energy Reviews 2014, 32, 559. [CrossRef]

${ }^{8}$ Titirici, M.-M.; Antonietti, M. Chemistry and Materials Options of Sustainable Carbon Materials Made by Hydrothermal Carbonization. Chemical Society Reviews 2010, 39, 103. [CrossRef]

${ }^{9}$ Falco, C.; Baccile, N.; Titirici, M.-M. Morphological and Structural Differences between Glucose, Cellulose and Lignocellulosic Biomass Derived Hydrothermal Carbons. Green Chemistry 2011, 13, 3273. [CrossRef]

${ }^{10}$ Heilmann, S. M.; Davis, H. T.; Jader, L. R.; Lefebvre, P. A.; Sadowsky, M. J.; Schendel, F. J.; von Keitz, M. G.; Valentas, K. J. Hydrothermal Carbonization of Microalgae. Biomass and Bioenergy 2010, 34, 875. [CroosRef]

${ }^{11} \mathrm{Hu}$, B.; Yu, S.-H.; Wang, K.; Liu, L.; Xu, X.-W. Functional Carbonaceous Materials from Hydrothermal Carbonization of Biomass: An Effective Chemical Process. Dalton Transactions 2008, 40, 5414. [CrossRef]

${ }^{12} \mathrm{Hu}$, B.; Wang, K.; Wu, L.; Yu, S.-H.; Antonietti, M.; Titirici, M.-M. Engineering Carbon Materials from the Hydrothermal Carbonization Process of Biomass. Advanced Materials 2010, 22, 813. [CrossRef]

${ }^{13}$ Nizamuddin, S.; Shrestha, S.; Athar, S.; Ali, B. S.; Siddiqui, M. A. A Critical Analysis on Palm Kernel Shell from Oil Palm Industry as a Feedstock for Solid Char Production. Reviews in Chemical Engineering 2016, 32, 489. [CrossRef]

${ }^{14}$ Souza, M. P.; Borrero, M. A. V.; Souza-Filho, T.A. Potencial para o Desenvolvimento da Cadeia Produtiva do Babaçu no Médio e Baixo Rio Madeira - Porto Velho/Ro. Revista de Admistração e Negócios da Amazônia 2011, 3, 75. [Link]

${ }^{15}$ Carvalho, J. D. V. Dossiê Técnico: Cultivo de Babaçu e Extração Do Óleo. Centro de Apoio ao Desenvolvimento Tecnológico da 
Universidade de Brasília (CDT/UnB) - Serviço Brasileiro de Respostas Técnicas (SBRT), 2007. [Link]

${ }^{16}$ Teixeira, M. A. Babassu-A New Approach for an Ancient Brazilian Biomass. Biomass and Bioenergy 2008, 32, 857. [CrossRef]

${ }^{17}$ Soler, M. P.; Vitali, A. de A.; Muto, E. F. Tecnologia de Quebra Do Coco Babaçu (Orbignya Speciosa). Ciência e Tecnologia de Alimentos 2007, 27, 717. [Link]

${ }^{18}$ Albiero, D.; Maciel, A. J. da S.; Lopes, A. C.; Mello, C. A.; Gamero, C. A. Proposal of Harvest's Babaçu Machine (Orbignya Phalerata Mart.) for the Small Farms. Acta Amazonica 2007, 37, 337. [CrossRef]

${ }^{19}$ Carrazza, L. R.; Ávila, J. C. C. e; Silva, M. L. da. Manual Tecnológico: Aproveitamento Integral do Fruto do Babaçu. Instituto Sociedade População e Natureza (ISPN) 2012. [Link]

${ }^{20}$ Cunha da Costa, R. Potential for Producing Bio-Fuel in the Amazon Deforested Areas. Biomass and Bioenergy 2004, 26, 405. [CrossRef]

${ }^{21}$ Cinelli, B. A.; López, J. A.; Castilho, L. R.; Freire, D. M. G.; Castro, A. M. Granular Starch Hydrolysis of Babassu Agroindustrial Residue: A Bioprocess within the Context of Biorefinery. Fuel 2014, 124, 41. [CrossRef]

${ }^{22}$ Maniglia, B. C.; Tapia-Blácido, D. R. Isolation and Characterization of Starch from Babassu Mesocarp. Food Hydrocolloids 2016, 55, 47. [CrossRef]

${ }^{23}$ Nascimento, F. R.; Barroqueiro, E. S.; Azevedo, A. P.; Lopes,A.S.; Ferreira, S.C.; Silva, L.A.; Maciel, M.C.; Rodriguez, D.; Guerra, R.N.Macrophage activation induced by Orbignya phalerata Mart. Journal of Ethnopharmacology 2005, 103, 53. [CrossRef] [PubMed]

${ }^{24}$ Carneiro, A. P. M.; Pascoal, L. A. F.; Watanabe, P. H.; Santos, I. B.; Lopes, J. M.; Arruda, J. de C. B. Farelo de Babaçu em Rações para Frangos de Corte na Fase Final: Desempenho E Avaliação Economica. Ciência Animal Brasileira 2009, 10, 40. [Link]
${ }^{25}$ Miotto, F. R. C.; Restle, J.; Neiva, J. N. M.; Castro, K. J. de; Sousa, L. F.; Silva, R. de O. da; Freitas, B. B. de; Leão, J. P. Replacement of Corn by Babassu Mesocarp Bran in Diets for Feedlot Young Bulls. Revista Brasileira de Zootecnia 2013, 42, 213. [CrossRef]

${ }^{26}$ Santana, A. E. M.; Neiva, J. N. M.; Restle, J.; Sousa, L. F.; Miotto, F. R. C.; Araújo, V. L. de; Alencar, W. M.; Augusto, W. F. Babassu Mesocarp Bran Levels Associated with Whole or Ground Corn Grains in the Finishing of Young Bulls: Carcass and Meat Characteristics. Revista Brasileira de Zootecnia 2014, 43, 607. [CrossRef]

${ }^{27}$ Ghosh, A.; Razzino, C. do A.; Dasgupta, A.; Fujisawa, K.; Vieira, L. H. S.; Subramanian, S.; Costa, R. S.; Lobo, A. O.; Ferreira, O. P.; Robinson, J.; Terrones, M.; Terrones, H.; Viana, B.C. Structural and Electrochemical Properties of Babassu Coconut MesocarpGenerated Activated Carbon and Few-Layer Graphene. Carbon 2019, 145, 175. [Link]

${ }^{28}$ Filho, S.; Da, C. G.; Milioli, F. E. A Thermogravimetric Analysis of the Combustion of a Brazilian Mineral Coal. Química Nova 2008, 31, 98. [CrossRef]

${ }^{29}$ García, R.; Pizarro, C.; Lavín, A. G.; Bueno, J. L. Biomass Proximate Analysis Using Thermogravimetry. Bioresource Technology 2013, 139, 1. [CrossRef]

${ }^{30}$ Ahmad, M.; Subawi, H. New Van Krevelen diagram and its correlation with theheating value of biomass. Research Journal of Agriculture and Environmental Management 2013, 2, 295. [Link]

${ }^{31}$ Oliveira, I.; Blöhse, D.; Ramke, H.-G. Hydrothermal Carbonization of Agricultural Residues. Bioresource Technology 2013, 142, 138. [CrossRef]

${ }^{32}$ Liu, Z.; Quek, A.; Kent Hoekman, S.; Srinivasan, M. P.; Balasubramanian, R. Thermogravimetric Investigation of Hydrochar-Lignite Co-Combustion. Bioresource Technology 2012, 123, 646. [CrossRef]

${ }^{33}$ Boundy, R. G.; Diegel, S. W.; Wright, L. L.; Davis, S. C. Biomass Energy Data Book, 4th ed. 
U.S.Department of Energy - Office of the Biomass Program: United States, 2011. [Link]

${ }^{34}$ Miranda, V. R.; Carvalho, A. J. F. Blendas Compatíveis de Amido Termoplástico e Polietileno de Baixa Densidade Compatibilizadas Com Ácido Cítrico. Polímero s2011, 21, 353. [CrossRef]

${ }^{35}$ Sevilla, M.; Fuertes, A. B. The Production of Carbon Materials by Hydrothermal Carbonization of Cellulose. Carbon 2009, 47, 2281. [CrossRef]

${ }^{36}$ Lima, B. N. B.; Cabral, T. B.; Neto, C.; P, R.; Tavares, M. I. B.; Pierucci, A. P. T. Characterization of Commercial Edible Starch Flours. Polímeros 2012, 22, 486. [CrossRef]

${ }^{37}$ Souza, R. C. R.; Andrade, C. T. Investigation of Corn Starch Gelatinization and Extrusion Processes. Polímeros 2000, 10, 24. [CrossRef]

${ }^{38}$ Parris, N.; Dickey, L. C. Extraction and Solubility Characteristics of Zein Proteins from Dry-Milled Corn. Journal of Agricultural andFood Chemistry 2001, 49, 3757. [Link] [PubMed]
${ }^{39}$ Forato, L. A.; Britto, D. de; Scramin, J. A.; Colnago, L. A.; Assis, O. B. G. Propriedades Mecânicas e Molhabilidade de Filmes de Zeínas Extraídas de Glúten de Milho. Polímeros 2013, 23, 42. [CrossRef]

${ }^{40}$ Ferrari, A. C.; Robertson, J. Interpretation of Raman Spectra of Disordered and Amorphous Carbon. Physical Revew B 2000, 61, 14095. [CrossRef]

${ }^{41}$ Ryu, J.; Suh, Y.-W.; Suh, D. J.; Ahn, D. J. Hydrothermal Preparation of Carbon Microspheres from Mono-Saccharides and Phenolic Compounds. Carbon 2010, 48, 1990. [CrossRef]

${ }^{42}$ Nieto-Márquez Ballesteros, A. Tese de doutorado, Universidad de Castilla-La mancha, Espanha, 2010. [Link]

${ }^{43}$ Zhang, M.; Yang, H.; Liu, Y.; Sun, X.; Zhang, D.; Xue, D. Hydrophobic Precipitation of Carbonaceous Spheres from Fructose by a Hydrothermal Process. Carbon 2012, 50, 2155. [CrossRef] 